\title{
A new missense mutation in the paired domain of the mouse Pax3 gene
}

\author{
Tamio OHNO ${ }^{1)}$, Tomoki MAEGAWA ${ }^{1)}$, Hiroto KATOH ${ }^{1)}$, Yuki MIYASAKA ${ }^{1)}$, Miyako SUZUKI ${ }^{2)}$, \\ Misato KOBAYASHI ${ }^{2}$, and Fumihiko HORIO ${ }^{2)}$ \\ 1) Division of Experimental Animals, Graduate School of Medicine, Nagoya University, 65 Tsurumai-cho, Showa-ku, \\ Nagoya, Aichi 466-8550, Japan \\ ${ }^{2)}$ Department of Applied Molecular Bioscience, Graduate School of Bioagricultural Sciences, Nagoya University, \\ Furo-cho, Chikusa-ku, Nagoya, Aichi 464-8601, Japan
}

\begin{abstract}
Mice with dominant white spotting occurred spontaneously in the C3.NSY-(D11Mit74D11Mit229) strain. Linkage analysis indicated that the locus for white spotting was located in the vicinity of the Pax3 gene on chromosome 1. Crosses of white-spotted mice showed that homozygosity for the mutation caused tail and limb abnormalities and embryonic lethality as a result of exencephaly; these phenotypes were analogous to those found in other Pax3 mutants. Sequence analysis identified a missense point mutation (c.101G>A) in exon 2 of $P a x 3$ that resulted in a methionine to isoleucine conversion at amino acid 62 of the PAX3 protein. This mutation site was located in the $\mathrm{N}$-terminal HTH (helix-turn-helix) motif of the paired domain of $P a x 3$, which is necessary for binding to DNA and is highly conserved in vertebrate species. Alteration of DNA binding affinity was responsible for embryonic lethality in homozygotes and white spotting in heterozygotes. We named the mutant allele as $P a x 3^{S p-N a g}$. The $\mathrm{C} 3 \mathrm{H} / \mathrm{HeN}-\mathrm{Pax} 3^{\mathrm{Sp}-\mathrm{Nag}}$ strain may be useful for analyzing the function of $P a x 3$ as a new model of the human disease, Waardenburg Syndrome.

Key words: embryonic lethal, missense mutation, mouse, Pax3 gene, white spotting
\end{abstract}

\section{Introduction}

A number of gene mutations are associated with white spotting in mice, and mutations of orthologous genes have been shown to be responsible for human piebaldism and Waardenburg Syndrome (WS), which causes pigmentation defects and deafness [3, 12]. Many alleles of mouse genes have been identified, and functional analyses of them have provided considerable insights into the regulatory networks of melanocyte development $[3,12]$. The present report describes a spontaneous mutation that was first identified in a female mouse that showed small white spotting on its belly; the mouse belonged to the C3.NSY-(D11Mit74-D11Mit229) congenic strain. This new white spotting phenotype showed autosomal dominant inheritance, and we provisionally named the mutation Dws(dominant white spotting). We backcrossed mutant mice to $\mathrm{C} 3 \mathrm{H} / \mathrm{HeN}$, the recipient strain of the C3.NSY-(D11Mit74-D11Mit229) congenic strain, and generated the $\mathrm{C} 3 \mathrm{H} / \mathrm{HeN}-D$ ws strain (Fig. 1). These mice were used to identify and characterize the $D w s$ mutation.

\section{Materials and Methods}

\section{Mice}

C3.NSY-(D11Mit74-D11Mit229) mice were obtained from the Experimental Animal Division, Riken BioResource Center (Tsukuba, Japan). C3H/HeN (C3H) mice

(Received 30 January 2017 / Accepted 13 March 2017 / Published online in J-STAGE 6 April 2017)

Address corresponding: T. Ohno, Division of Experimental Animals, Graduate School of Medicine, Nagoya University, 65 Tsurumai-cho, Showa-ku, Nagoya, Aichi 466-8550, Japan

Supplementary Tables: refer to J-STAGE: https://www.jstage.jst.go.jp/browselexpanim

(C2017 Japanese Association for Laboratory Animal Science 

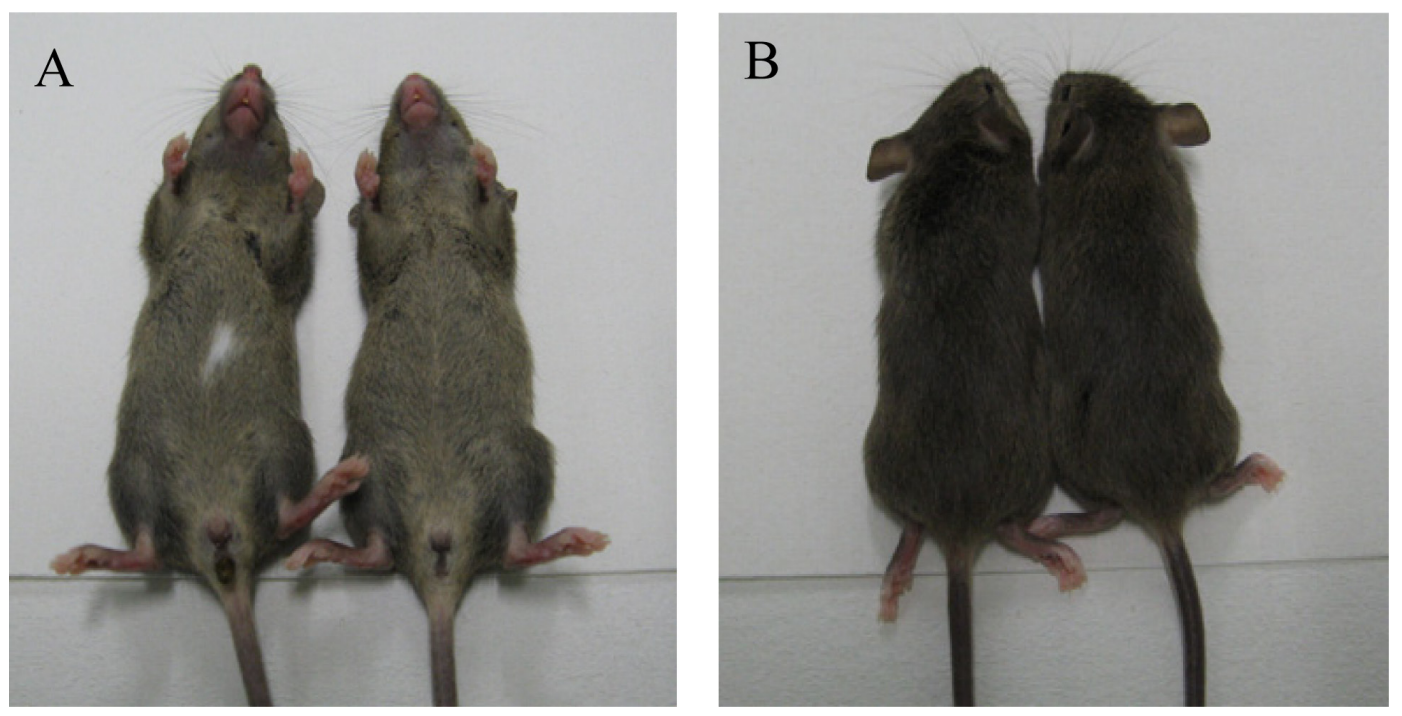

Fig. 1. Coat color of white-spotted (left: $D w s /+$ ) and wild-type (right: +/+) mice. (A) Ventral view, (B) dorsal view.

were purchased from Charles River Laboratories Japan (Yokohama, Japan), and C57BL/6J (B6J) mice were purchased from Japan SLC (Hamamatsu, Japan). All mice were fed a commercial CE-2 diet (CLEA Japan, Tokyo) and had ad libitum access to water. The mice were bred in a pathogen-free facility at the Institute for Laboratory Animal Research, Graduate School of Medicine, Nagoya University, and maintained under a controlled temperature of $23 \pm 1{ }^{\circ} \mathrm{C}$, humidity of $55 \pm 10 \%$, and a light cycle of $12 \mathrm{~h} \mathrm{light} \mathrm{(from} \mathrm{09:00} \mathrm{to} \mathrm{21:00)/12} \mathrm{h} \mathrm{dark} \mathrm{(from} \mathrm{21:00}$ to 09:00). Animal care and all experimental procedures were approved by the Animal Experiment Committee, Graduate School of Medicine, Nagoya University, and were conducted according to the Regulations on Animal Experiments of Nagoya University.

\section{Genetic mapping}

Approximately half of the $(\mathrm{B} 6 \mathrm{~J} \times \mathrm{C} 3 \mathrm{H} / \mathrm{HeN}-D w s) \mathrm{F}_{1}$ male and female mice showed white belly spotting, confirming that this character is controlled by autosomal dominant inheritance. White-spotted $(\mathrm{B} 6 \mathrm{~J} \times \mathrm{C} 3 \mathrm{H} / \mathrm{HeN}$ $D w s) \mathrm{F}_{1}$ mice were backcrossed to B6J mice. Sixty-four white-spotted and 89 normal (no white spotting) mice were obtained from a total of 153 progeny in the backcross generation. Genomic DNA was prepared from tail tissue by salt/ethanol precipitation. PCR genotyping of simple sequence length polymorphism (SSLP) markers was performed according to standard methods. PCR products were separated by electrophoresis on a $4 \%$ NuSieve agarose gel (FMC, Rockland, ME, USA) and visualized by UV light after ethidium bromide staining. Linkage of markers to white spotting was evaluated by $\chi^{2}$-tests. Genotype distribution was compared with the theoretical expectation based on Mendelian segregation.

\section{Phenotype of homozygous (Dws/Dws) embryos}

Crosses between heterozygous ( $D w s /+)$ mice failed to produce any overt homozygous offspring in a preliminary study. To confirm the embryonic lethality of the homozygous mutant genotype, we examined 18 pregnant whitespotted $(\mathrm{B} 6 \mathrm{~J} \times \mathrm{C} 3 \mathrm{H} / \mathrm{HeN}-D w s) \mathrm{F}_{1}$ females that had been crossed with white-spotted $(\mathrm{B} 6 \mathrm{~J} \times \mathrm{C} 3 \mathrm{H} / \mathrm{HeN}-D w s) \mathrm{F}_{1}$ males. The pregnant females were euthanized by isoflurane inhalation on days 14.5 to 17.5 of pregnancy, and embryos were rapidly extracted for analysis. The genotypes of the embryos were determined as described above.

\section{Sequence analysis}

Our mapping analysis identified $\operatorname{Pax} 3$ as a candidate for the mutation. To confirm this, we analyzed the gene structure in the mutant by amplifying the coding region (9 exons) and splice junctions using the primer pairs listed in Table S1. Primer sequences were designed using genome assembly data (GRCm38.p4) as the reference sequence. PCR amplification was performed using a KOD Plus (TOYOBO, Osaka, Japan), and amplification products were purified using a QIAquick Gel Extraction Kit (QIAGEN, Hilden, Germany). PCR products were sequenced using the dideoxy chain-termination method with a BigDye Terminator v3.1 Cycle Sequencing Kit 
Table 1. Segregation ratios of neighboring markers at 8 candidate genes in the 64 white-spotted backcross progeny

\begin{tabular}{lrcccc}
\hline \multicolumn{1}{c}{ Marker } & Chr. & Position $(\mathrm{Mb})$ & Candidate gene (Position Mb) & Ratio (homo : hetero) & $\chi^{2}$-value \\
\hline D1Mit215 & 1 & 78.21 & Pax3 $(78.10-78.20)$ & $0: 64$ & 64.00 \\
D2Mit229 & 2 & 168.78 & Edn3 $(174.76-174.78)$ & $32: 32$ & 0.00 \\
D5Mit355 & 5 & 71.9 & Kit $(75.57-75.67)$ & $26: 38$ & 2.25 \\
D6Mit149 & 6 & 106.01 & Mitf $(97.81-98.02)$ & $29: 35$ & 0.56 \\
D10Mit96 & 10 & 99.56 & Kitl $(100.02-100.10)$ & $34: 30$ & 0.25 \\
D14Mit92 & 14 & 91.11 & Ednrb $(103.81-103.84)$ & $29: 35$ & 0.56 \\
D15Mit63 & 15 & 65.25 & Sox10 $(79.15-79.16)$ & $35: 29$ & 0.56 \\
D16Mit131 & 16 & 7.32 & Snai2 $(14.71-14.71)$ & $28: 36$ & 1.00 \\
\hline
\end{tabular}

Table 2. Genetic mapping of the Dws locus using SSLP markers around the $\operatorname{Pax} 3$ gene

\begin{tabular}{lcccc}
\hline Marker & Position (Mb) & $\begin{array}{c}\text { White spotting } \\
\text { (homo }: \text { hetero) }\end{array}$ & $\begin{array}{c}\text { Normal } \\
\text { (homo : hetero) }\end{array}$ & $\chi^{2}$-value \\
\hline D1Mit484 & 76.39 & $1: 63$ & $77: 12$ & 107.53 \\
D1Mit132 & 77.15 & $0: 64$ & $77: 12$ & 111.47 \\
Pax3 & $78.10-78.20$ & & & \\
D1Mit215 & 78.21 & $0: 64$ & $78: 11$ & 114.44 \\
D1Mit81 & 85.76 & $0: 64$ & $74: 15$ & 103.11 \\
D1Mit49 & 87.2 & $1: 63$ & $74: 15$ & 99.17 \\
\hline
\end{tabular}

Table 3. Incidence of malformed embryos of each genotype for D1Mit215 on different days of gestation

\begin{tabular}{cccccr}
\hline Fetal age & No. of embryos & Average litter size & $\begin{array}{c}\text { Number of embryos } \\
\text { (B6J/B6J:B6J/C3H:C3H/C3H) }\end{array}$ & $\begin{array}{c}\text { Number of malformed embryos } \\
\text { (B6J/B6J:B6J/C3H:C3H/C3H) }\end{array}$ & $\begin{array}{l}\text { Incidence * } \\
\text { E14.5 }\end{array}$ \\
E15.5 & 29 & $8.3(33 / 4)$ & $9: 18: 6$ & $0: 0: 4$ & $67 \%(4 / 6)$ \\
E16.5 & 33 & $7.3(29 / 4)$ & $12: 11: 6$ & $0: 0: 5$ & $83 \%(5 / 6)$ \\
E17.5 & 39 & $6.3(33 / 4)$ & $6: 21: 6$ & $0: 0: 5$ & $83 \%(5 / 6)$ \\
\hline
\end{tabular}

(Applied Biosystems, Foster City, CA, USA) and then analyzed on an ABI 3500 (Applied Biosystems) automated DNA sequencer.

\section{Results}

\section{Genetic mapping}

SSLP markers that showed polymorphisms between B6J and $\mathrm{C} 3 \mathrm{H}$ were used to scan eight candidate genes (Edn3, Ednrb, Kit, Kitl, Mitf, Pax3, Sox10, and Snai2) for linkage with the white spotting phenotype [3]. The segregation data for the 64 white-spotted mice in the backcross generation are shown for each candidate gene in Table 1. All of the white-spotted mice were heterozygous $(\mathrm{B} 6 \mathrm{~J} / \mathrm{C} 3 \mathrm{H})$ at the D1Mit215 locus, which is close to Pax3. The other seven markers showed no indication of linkage to white spotting. Our results indicated that the $D$ ws locus was likely located in the vicinity of Pax3. Five SSLP markers on chromosome 1 were used to confirm the location of the mutation and map it more pre- cisely (Table 2). D1Mit215, which was the closest of these markers to $P a x 3$, showed the largest deviation from the expected ratio. These results suggested that $D w s$ was likely a mutation of the $\operatorname{Pax} 3$ gene. The presence of 11 heterozygous $(\mathrm{B} 6 \mathrm{~J} / \mathrm{C} 3 \mathrm{H})$ mice at the D1Mit215 locus with a normal (no white spotting) phenotype in the backcross generation indicated the incomplete gene penetrance of Dws. The penetrance appeared to be about $85.3 \%(64 / 64+11$; Table 2$)$.

\section{Embryonic lethality of the homozygous genotype}

We analyzed $\mathrm{F}_{2}$ embryos produced by intercrosses of white-spotted $(\mathrm{B} 6 \mathrm{~J} \times \mathrm{C} 3 \mathrm{H} / \mathrm{HeN}-D w s) \mathrm{F}_{1}$ mice (Table 3). Malformed embryos, characterized by exencephaly and tail and limb abnormalities (Fig. 2), were present from E14.5 to E17.5. The phenotype of the malformed embryos was similar to those described for other Pax3 mutants, such as $\operatorname{Pax}^{S p}, \operatorname{Pax}^{S p-1 H}, \operatorname{Pax}^{S p-2 H}, \operatorname{Pax}^{S p-}$ ${ }^{I X z g}, P^{P a x} 3^{S p-1 W l i}$, and $P a x 3^{R w a}[2,5-7,10,14]$. There was an extremely small number of homozygous $(\mathrm{C} 3 \mathrm{H} / \mathrm{C} 3 \mathrm{H})$ 


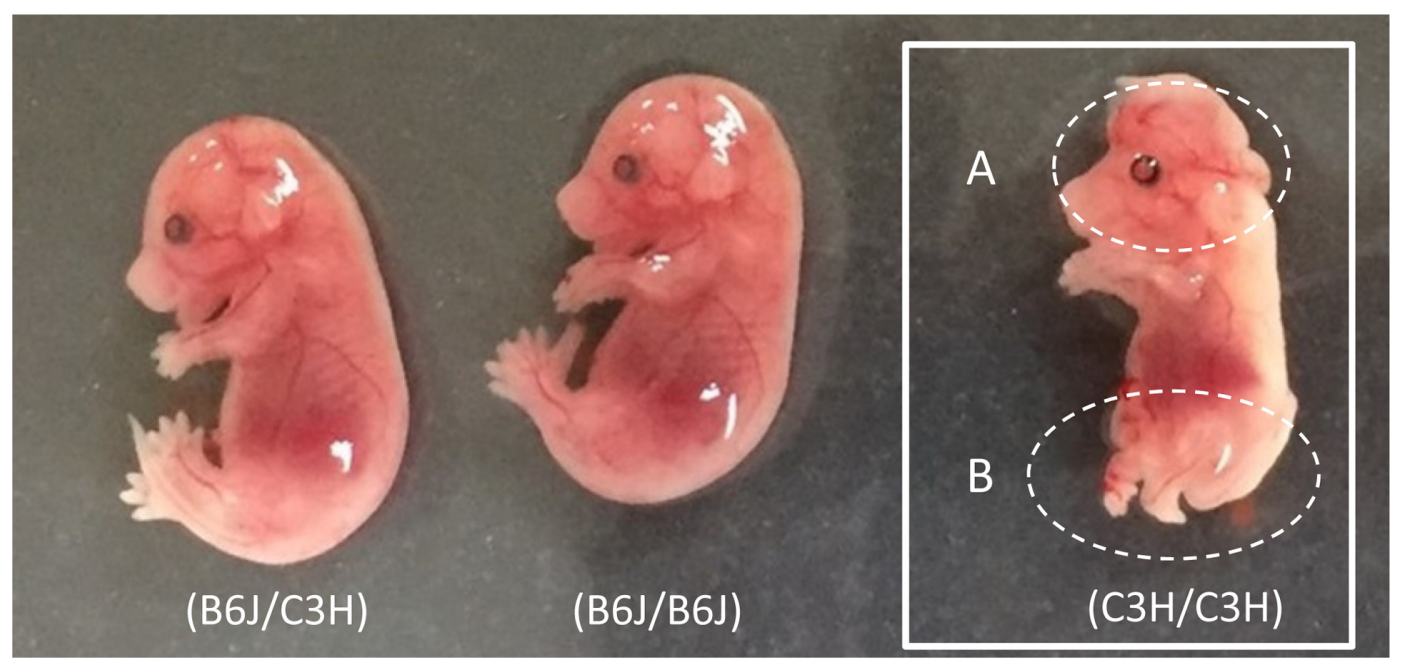

Fig. 2. E15.5 embryos of the $\mathrm{F}_{2}$ generation. D1Mit215 genotypes are shown in parentheses. (A) Exencephaly, (B) tail and limb abnormalities.

embryos, and litter size tended to be reduced, with the occasional occurrence of fetal death (data not shown) at E17.5. Genotyping analysis using D1Mit215 indicated that all the abnormal embryos were homozygous for the $\mathrm{C} 3 \mathrm{H}$-derived allele. The rate of malformed homozygous embryos $(\mathrm{C} 3 \mathrm{H} / \mathrm{C} 3 \mathrm{H})$ tended to increase with embryonic age. These facts suggested the embryonic lethality of $D w s / D w s$ mice.

\section{Sequence of the Pax3 gene in mutants}

A missense point mutation, $\mathrm{G}$ to $\mathrm{A}$, was identified at nucleotide 101 in exon 2 of the Pax3 gene (Fig. 3). This alteration resulted in a methionine to isoleucine conversion at amino acid 62 (p.Met62Ile) in highly conserved region among vertebrate species of the PAX3 protein (Fig. 3 and Table 4).

\section{Discussion}

Pax3 encodes a transcription factor that is important in melanocytes and influences melanocytic proliferation, resistance to apoptosis, migration, lineage specificity, and differentiation [9]. The gene possesses four structural domains: a paired domain, an octapeptide motif, a homeodomain, and a transactivation domain. The paired domain, named after the two helix-turn-helix (HTH) motif-containing sub-domains within it, binds DNA in addition to facilitating interactions with other proteins [9]. The N-terminal HTH motif (amino acid residue 54-94) is necessary and sufficient for binding to DNA, and is highly conserved among vertebrate species [9]. The mutation identified here is located within the Nterminal HTH motif in the paired domain of the Pax3 gene (Fig. 3). Several human $P A X 3$ mutations occur as missense or frameshift mutations within the highly conserved region of exon 2, which gives rise to part of the paired domain $[9,11]$. Although exactly the same mutation have not been reported, a mutation on same amino acid (p.Met62Val) within the paired domain has been reported in human $P A X 3$. The patient with this mutation exhibited dystopia canthorum and confluent eyebrows as WS features [8]. It is likely that the amino acid change (p.Met62Ile) on the N-terminal HTH motif identified in this study would alter the DNA binding affinity of the paired domain and would underlie the loss of $\operatorname{Pax} 3$ function. We formally named $D w s$ as $P a x 3^{S p-N a g}$.

Modifier genes of Pax 3 mutant alleles have been reported $[1,7]$, and they expand our understanding of the complex network governing melanocyte development. Large size variations in white spotting on the belly were observed among the 64 white-spotted mice of the backcross generation, but such size variation was relatively small in the $\mathrm{C} 3 \mathrm{H} / \mathrm{HeN}-\mathrm{Pax}^{\mathrm{Sp}-\mathrm{Nag}}$ strain. This suggests that $P a \times 3^{S p-N a g}$ modifier genes are present in the B6J genetic background. To screen the interaction between modifier and mutant genes, thirteen backcross mice that showed relatively large white spots were selected and genotyped using markers located in the vicinity of seven WS candidate genes (Edn3, Ednrb, Kit, Kitl, Mitf, Sox10, and Snai2). None of the markers showed a distribution 
A

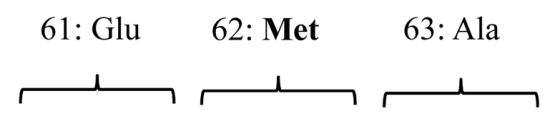

\section{Wild-type \\ $\mathrm{C} 3 \mathrm{H} / \mathrm{HeN}$}

White spotting

$(\mathrm{B} 6 \mathrm{~J} \times \mathrm{C} 3 \mathrm{H} / \mathrm{HeN}-D w s /+) \mathrm{F}_{1}$

Malformed embryo

$(\mathrm{B} 6 \mathrm{~J} \times \mathrm{C} 3 \mathrm{H} / \mathrm{HeN}-\mathrm{Dws} /+) \mathrm{F}_{2}$
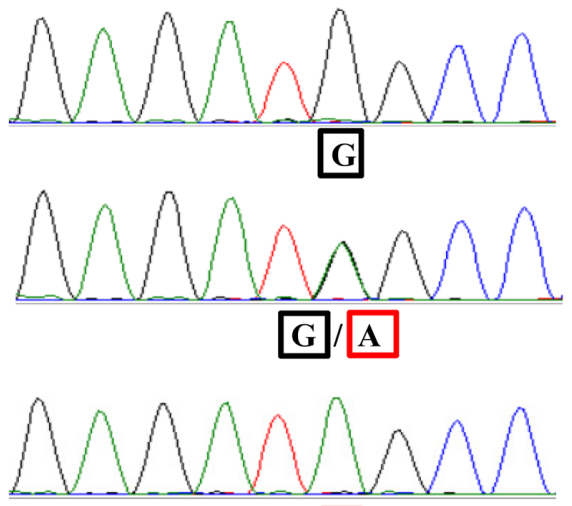

A

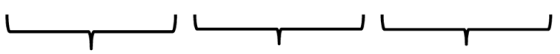

61: Glu 62: Ile 63: Ala

B

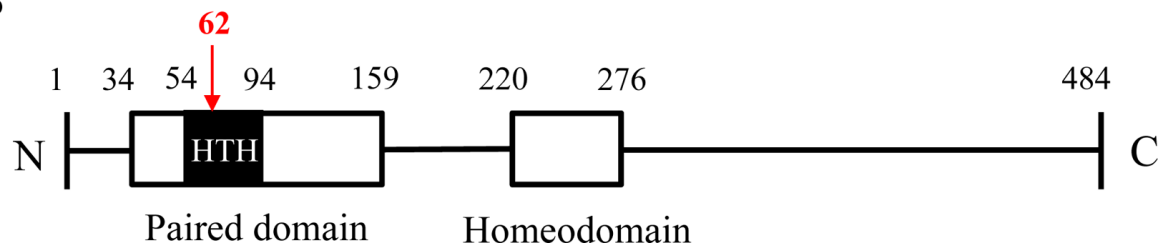

Fig. 3. (A) Missense mutation in the Pax3 gene of the Dws mutant. A c.101 G>A transition in exon 2 causes the conversion of Met to Ile at amino acid 62. (B) Schematic diagram of the mouse PAX3 protein including homeodomain and paired domain with $\mathrm{N}$-terminal HTH motif. Numbers correspond to the amino acid sequence.

Table 4. Multiple sequence alignments of PAX3 protein from various species

\begin{tabular}{|c|c|c|c|c|c|c|c|c|c|c|c|c|c|c|c|c|c|}
\hline \multirow{2}{*}{ Species } & \multicolumn{17}{|c|}{ Number of the amino acid sequence of PAX3 } \\
\hline & 54 & & & & & & & & 62 & & & & & & & & 70 \\
\hline Mouse (Pax $\left.3^{S p-N a g} / \mathrm{Pax}^{\mathrm{Sp}-\mathrm{Nag}}\right)$ & $\mathrm{H}$ & I & $\mathrm{R}$ & $\mathrm{H}$ & $\mathrm{K}$ & I & V & $\mathrm{E}$ & $\mathbf{I}$ & A & $\mathrm{H}$ & $\mathrm{H}$ & $\mathrm{G}$ & I & $\mathrm{R}$ & $P$ & $\mathrm{C}$ \\
\hline Mouse (Mus musculus) & $\mathrm{H}$ & I & $\mathrm{R}$ & $\mathrm{H}$ & $\mathrm{K}$ & I & V & E & M & A & $\mathrm{H}$ & $\mathrm{H}$ & $\mathrm{G}$ & I & $\mathrm{R}$ & $\mathrm{P}$ & $\mathrm{C}$ \\
\hline Human (Homo sapiens) & $\mathrm{H}$ & I & $\mathrm{R}$ & $\mathrm{H}$ & $\mathrm{K}$ & I & V & E & M & A & $\mathrm{H}$ & $\mathrm{H}$ & $\mathrm{G}$ & I & $\mathrm{R}$ & $\mathrm{P}$ & $\mathrm{C}$ \\
\hline Monkey (Macaca fascicularis) & $\mathrm{H}$ & I & $\mathrm{R}$ & $\mathrm{H}$ & $\mathrm{K}$ & I & V & $\mathrm{E}$ & M & A & $\mathrm{H}$ & $\mathrm{H}$ & G & I & $\mathrm{R}$ & $\mathrm{P}$ & $\mathrm{C}$ \\
\hline Turkey (Meleagris gallopavo) & $\mathrm{H}$ & I & $\mathrm{R}$ & $\mathrm{H}$ & $\mathrm{K}$ & I & V & E & M & A & $\mathrm{H}$ & $\mathrm{H}$ & $\mathrm{G}$ & I & $\mathrm{R}$ & $\mathrm{P}$ & $\mathrm{C}$ \\
\hline Sea turtle (Chelonia mydas) & $\mathrm{H}$ & I & $\mathrm{R}$ & $\mathrm{H}$ & $\mathrm{K}$ & I & $\mathrm{V}$ & E & M & A & $\mathrm{H}$ & $\mathrm{H}$ & G & I & $\mathrm{R}$ & $\mathrm{P}$ & $\mathrm{C}$ \\
\hline Frog (Xenopus laevis) & $\mathrm{H}$ & I & $\mathrm{R}$ & $\mathrm{H}$ & K & I & V & $\mathrm{E}$ & M & A & $\mathrm{H}$ & $\mathrm{H}$ & G & I & $\mathrm{R}$ & $\mathrm{P}$ & $\mathrm{C}$ \\
\hline Flatfish (Paralichthys olivaceus) & $\mathrm{H}$ & I & $\mathrm{R}$ & $\mathrm{H}$ & $\mathrm{K}$ & I & $\mathrm{V}$ & E & M & $\mathrm{A}$ & $\mathrm{H}$ & $\mathrm{H}$ & G & I & $\mathrm{R}$ & $\mathrm{P}$ & $\mathrm{C}$ \\
\hline
\end{tabular}

disequilibrium from the expected ratio (Table S2). This suggests that the size variation in white spotting mediated by $\operatorname{Pax}^{\text {Sp-Nag }}$ allele was not a consequence of a direct interaction with other candidate WS genes.

During breeding of $\mathrm{C} 3 \mathrm{H} / \mathrm{HeN}-\mathrm{Pax}^{\text {Sp-Nag }}$ mice, males with white spotting were crossed with wild type females. The incidence of white-spotted offspring was $41.2 \%$ $(21 / 51)$, which is lower than the expected ratio of $50 \%$ of the mice with the mutation phenotype. The reduction in the incidence of white-spotted mice from the expected ratio in the $\mathrm{C} 3 \mathrm{H} / \mathrm{HeN}-\mathrm{Pax}^{\mathrm{Sp}-\mathrm{Nag}}$ strain is in accordance with incomplete gene penetrance (85.3\%). Whitespotted mice with tail abnormalities, e.g., looped tails, were rarely observed $(<1 \%)$ in this strain. The looped tail feature was not passed on to the next generation. Although the cause is not known, a similar phenomenon has been reported for other Pax 3 mutant mice such as $\operatorname{Pax}^{S p-1 H}, \operatorname{Pax}^{\text {Sp-1Xzg }}$, and $\operatorname{Pax}^{\text {Rwa }}[6,10,14]$. Hetero- 
Table 5. Pax3 mutations and mutant phenotypes

\begin{tabular}{llll}
\hline \multirow{2}{*}{ Allele } & \multicolumn{1}{c}{ Mutation } & \multicolumn{2}{c}{ Phenotype } \\
\cline { 3 - 4 } & & Homozygous & Heterozygous \\
\hline $\operatorname{Pax}^{R w a}$ & 841 bp deletion spanning the promoter region and intron 1 & Embryonic lethal & Belly white spotting \\
$\operatorname{Pax}^{S p-7 H}$ & Missense mutation (V38G) in exon 2 (paired domain) & Embryonic lethal & Belly white spotting \\
$\operatorname{Pax}^{S p-d}$ & Missense mutation (G42R) in exon 2 (paired domain) & Perinatal lethal & Belly white spotting \\
$\operatorname{Pax}^{S p-N a g}$ & Missense mutation (M62I) in exon 2 (paired domain) & Embryonic lethal & Belly white spotting \\
$\operatorname{Pax}^{S p-1 W l i}$ & Nonsense mutation (K107X) in exon 2 (paired domain) & Embryonic lethal & Belly white spotting \\
$\operatorname{Pax}^{S p}$ & Point mutation of splice acceptor of intron 3 & Embryonic lethal & Belly white spotting \\
$\operatorname{Pax}^{S p-2 H}$ & 32 bp deletion in exon 5 (homeodomain) & Embryonic lethal & Belly white spotting \\
$\operatorname{Pax}^{S p-1 X z g}$ & Missense mutation (N269D) in exon 6 (homeodomain) & Embryonic lethal & Belly white spotting \\
\hline
\end{tabular}

zygous ( $\mathrm{Pax} 3^{\mathrm{Sp}-\mathrm{Nag} /+}$ ) mice with the p.Met62Ile mutation do not appear to show deafness. Similarly, the patient with the p.Met62Val mutation of $P A X 3$ did not show deafness [8]. The missense mutation at amino acid 62 did not directly affect hearing ability, although deafness is a frequent feature of WS patients and is observed at a rate of about $60 \%$ in case of type $1 \mathrm{WS}$, most of which are caused by $P A X 3$ mutations [11]. The underlying genetic mutation and the phenotype of several Pax 3 mutant alleles have been determined and listed in Table 5 [2, 4 , $6,7,10,13,14]$. Although a few Pax3 mutants, such as $P a x 3^{S p-d}, P_{a x} 3^{S p-7 H}$, and $P a x 3^{S p-1 W l i}$, have a mutation in paired the domain $[4,13,14]$, the $\operatorname{Pax}^{\text {Sp-Nag }}$ allele reported here is the first missense mutant in the $\mathrm{N}$-terminal HTH motif of the paired domain of $\operatorname{Pax} 3$ gene in mice.

In conclusion, the $\mathrm{C} 3 \mathrm{H} / \mathrm{HeN}-\mathrm{Pax} 3^{\mathrm{Sp}-\mathrm{Nag}}$ strain, which carries a new missense mutation in the paired domain of the mouse Pax3 gene, may be useful for analyzing the function of $\operatorname{Pax} 3$ with respect to human WS. This strain has been deposited in the Riken BioResource Center (Tsukuba, Japan) under the catalog number RBRC06568.

\section{References}

1. Asher, J.H. Jr., Harrison, R.W., Morell, R., Carey, M.L., and Friedman, T.B. 1996. Effects of $\operatorname{Pax} 3$ modifier genes on craniofacial morphology, pigmentation, and viability: a murine model of Waardenburg syndrome variation. Genomics 34: 285-298. [Medline] [CrossRef]

2. Auerbach, R. 1954. Analysis of the developmental effects of a lethal mutation in the house mouse. J. Exp. Zool. 127: 305-329. [CrossRef]

3. Baxter, L.L., Hou, L., Loftus, S.K., and Pavan, W.J. 2004. Spotlight on spotted mice: a review of white spotting mouse mutants and associated human pigmentation disorders. Pigment Cell Res. 17: 215-224. [Medline] [CrossRef]

4. Bogani, D., Warr, N., Elms, P., Davies, J., Tymowska-Lalanne, Z., Goldsworthy, M., Cox, R.D., Keays, D.A., Flint, J., Wilson, V., Nolan, P., and Arkell, R. 2004. New semidominant mutations that affect mouse development. Genesis 40 :
109-117. [Medline] [CrossRef]

5. Epstein, D.J., Vekemans, M., and Gros, P. 1991. Splotch $\left(S p^{2 H}\right)$, a mutation affecting development of the mouse neural tube, shows a deletion within the paired homeodomain of Pax-3. Cell 67: 767-774. [Medline] [CrossRef]

6. Franz, T. 1992. Neural tube defects without neural crest defects in splotch mice. Teratology 46: 599-604. [Medline] [CrossRef]

7. Guo, X.L., Ruan, H.B., Li, Y., Gao, X., and Li, W. 2010. Identification of a novel nonsense mutation on the Pax3 gene in ENU-derived white belly spotting mice and its genetic interaction with c-Kit. Pigment Cell Melanoma Res. 23: 252-262. [Medline] [CrossRef]

8. Hol, F.A., Geurds, M.P., Cremers, C.W., Hamel, B.C., and Mariman, E.C. 1998. Identification of two PAX3 mutations causing Waardenburg syndrome, one within the paired domain $(\mathrm{M} 62 \mathrm{~V})$ and the other downstream of the homeodomain (Q282X). Hum. Mutat. 11(Suppl 1): S145-S147. [Medline] [CrossRef]

9. Kubic, J.D., Young, K.P., Plummer, R.S., Ludvik, A.E., and Lang, D. 2008. Pigmentation PAX-ways: the role of Pax3 in melanogenesis, melanocyte stem cell maintenance, and disease. Pigment Cell Melanoma Res. 21: 627-645. [Medline] [CrossRef]

10. Ohnishi, T., Miura, I., Ohba, H., Shimamoto, C., Iwayama, Y., Wakana, S., and Yoshikawa, T. 2017. A spontaneous and novel Pax3 mutant mouse that models Waardenburg syndrome and neural tube defects. Gene 607: 16-22. [Medline] [CrossRef]

11. Pingault, V., Ente, D., Dastot-Le Moal, F., Goossens, M., Marlin, S., and Bondurand, N. 2010. Review and update of mutations causing Waardenburg syndrome. Hum. Mutat. 31: 391-406. [Medline] [CrossRef]

12. Tachibana, M., Kobayashi, Y., and Matsushima, Y. 2003. Mouse models for four types of Waardenburg syndrome. Pigment Cell Res. 16: 448-454. [Medline] [CrossRef]

13. Vogan, K.J., Epstein, D.J., Trasler, D.G., and Gros, P. 1993. The splotch-delayed $\left(S p^{d}\right)$ mouse mutant carries a point mutation within the paired box of the Pax-3 gene. Genomics 17: 364-369. [Medline] [CrossRef]

14. Xiao, Y., Zhang, L., He, K., Gao, X., Yang, L., He, L., Ma, G., and Guo, X. 2011. Characterization of a novel missense mutation on murine Pax3 through ENU mutagenesis. J. Genet. Genomics 38: 333-339. [Medline] [CrossRef] 